AWEJ for Translation \& Literary Studies, Volume 4, Number3. August 2020 DOI: http://dx.doi.org/10.24093/awejtls/vol4no3.1

Pp.3-16

\title{
Nature, Caged Birds, and Constrained Women: An Ecocritical Feminist Reading of Angela Carter's Story The Erl-King
}

\author{
Shadi S. Neimneh* \\ English Department, Faculty of Arts \\ Hashemite University \\ Zarqa , Jordan \\ Corresponding Author* \\ Halla A. Shureteh \\ English Department, Faculty of Arts \\ Hashemite University \\ Zarqa , Jordan
}

\begin{abstract}
:
In their feminist and postmodern readings of Angela Carter's fiction, critics have often eclipsed the presence of nature in her writings and the significance of non-human forms of life. This article addresses this critical gap, focusing on Carter's employment of birds and the greenwood in her story The Erl-King as a metaphor for gender roles and power relations. Hence, the alliance between her ecopoetics and feminist vision forms a case of "ecofeminism." In her defense of "minor" and oppressed forms of life, Carter makes her caged birds emblems of women imprisoned by patriarchy. Their liberation by the female narrator at the end of the story is not only a sign of resistance but also an indication of the essential harmony and mutual strength of women and nature. Surprisingly though, and before this unexpected end in which the narrator strangles the ErlKing with his own hair, nature is made complicit in the oppression of women rather than simply liberating. This can be explained through Carter's ambivalent brand of postmodern feminist poetics that rejects fixities and conventional binaries, unsettling the patriarchal myth that women are merely close to nature. Thus, Carter subverts feminist logic by exposing how women and nature are not only closely allied or opposed to patriarchy but also complicit in their own oppression. Moreover, she subverts the woman/nature dichotomy by making the Erl-King the epitome of a harmonious life in nature rather than plainly defending women as expected in feminist texts. Carter deconstructs established myths and conventional gender roles, accounting for subtle female desire in the process of articulating feminist poetics via nature.
\end{abstract}

Keywords: Carter, ecocriticism, The Erl-King, feminism, caged birds, imprisonment, nature/woman

Cite as: Neimneh, S.S., \& Shureteh, H. A. (2020). Nature, Caged Birds, and Constrained Women: An Ecocritical Feminist Reading of Angela Carter's Story The Erl-King. Arab World English Journal for Translation \& Literary Studies 4 (3)3-16.

DOI: http://dx.doi.org/10.24093/awejtls/vol4no3.1

Arab World English Journal for Translation \& Literary Studies

ISSN: 2550-1542 |www.awej-tls.org 


\section{Introduction:}

As an emerging field of cultural studies that began in the 1980s and 1990s, ecocriticism (or green cultural studies) explores possible relations between literature/culture and the natural scene. In her ecocritical defense of nature with all its non-human forms, Mellor (1997) maintains that "nature has no will or destiny," similar to those oppressed, and that "while humanity is embodied in the natural world, its interrelationship with its environment is a historical process in many ways and across cultures humanity dialectically interrelates with non-human nature" (p.12). Hence, nature and the non-human world become a favorite subject for study for literary critics, cultural theorists, and feminists among others. According to Barry (2009), ecocritics often "re-read major literary works from an ecocentric perspective, with particular attention to the representation of the natural world" (p. 254). For Glotfelty, ecocriticism is succinctly "the study of the relationship between literature and the physical environment" (in Dobie, 2012, p. 239). Ecocritics focus on the interrelationship between man and the natural environment, and thus can symbolically represent human interactions in terms of natural forces and phenomena. The case of feminist literature can serve as a good example because just as feminists look at the representation of women in literature and culture to counter oppression, ecocritics look at the depiction of nature in literature "as a way to renew a reader's awareness of the nonhuman world and his or her responsibility to sustain it" (in Dobie, 2012, p. 239). Both approaches are interested in exploring the relationship between literary texts and sociopolitical realities. For instance, gender (even race) relations and stereotypes can be expounded or criticized via the symbolic employment of animals and plants in literary texts. Therefore, the claims and preoccupations of feminism and ecocriticism, which converge in the term "ecofeminism," are often intertwined against patriarchal claims which often reduce women to nature (a silent objectified one) while preserving the rational realm of language and thinking for men. The abuses patriarchal man perpetrates against nature become tantamount to the exploitation and othering of women and subsequent oppression/subordination. ${ }^{1}$ One central claim of ecofeminism is that "there is a connection between environmental degradation and the subordination of women with the goal of identifying and fostering liberatory alternatives" (Vakoch, 2012, p. 12). Hence, ecofeminists see that associating women with nature is a direct source of sexism and oppression that should be overcome to find empowering options.

Tyson (2006) contends that wherever patriarchy dominates, "woman is other: she is objectified and marginalized, defined only by her difference from male norms and values, defined by what she (allegedly) lacks and that men (allegedly) have" (p. 92; emphasis original). Patriarchy others woman as "the second sex" and even as "the absolute Other" (p. 1407) in the words of de Beauvoir in her 1949 book The Second Sex (in Leitch, 2001). On the other hand, Bennett and Royle (2009) argue that environmental problems, climate change, and destruction of wildlife are real challenges in our world today: "These challenges are all interrelated in different and highly complex ways, but at their core is the violence of what is called anthropocentrism" (p. 152). As man views himself at the center of the universe, man marginalizes nature and non-humans. The prominent French critic Derrida (2008) philosophically examined how animals, his cat in one particular case confronting him naked in the bathroom, make us think about "the wholly other"

Arab World English Journal for Translation \& Literary Studies 
that is the singular animal (p. 11). Anthropocentrism and humancentrism value human life as the most important form of being in the universe, and thus subordinate non-human forms of life like those of animals and plants. Both patriarchy and anthropocentrism partake in the process of "othering" women and non-human forms of life respectively.

The ecocritical relevance of Carter's fiction has not been adequately examined so far. A reading of Carter's story The Erl-King (published as the fifth story in Carter's collection The Bloody Chamber in 1979) reveals many interesting, yet blatantly unexplored, parallels with theoretical assumptions and other literary works regarding the alliance between oppressed women and nature as well as the ecofeminist potential of her works. One example of a relevant text in this regard comes from drama. In Susan Glaspell's renowned feminist one-act play, Trifles (1916), Mr. Wright is strangled with a rope. This mysterious murder is the retaliation of a woman against her oppressive husband for killing her pet bird. The women guests discover an empty broken birdcage and then find a dead bird strangled similarly as John Wright. They hide this evidence by way of being sympathetic to Mrs. Wright who was unhappily married and used to sing before being oppressed in a marital relationship. The rope round his neck (together with the bird that had its neck wrung) is reminiscent of the rings round the birds' necks in Carter's story The Erl-King. The dead canary was symbolically strangled, its neck was forcibly twisted, and the wife retaliated in a similar fashion. Because it was dear to her, the canary was left in the kitchen in the wife's sewing basket. Like the dead bird in the sewing basket, women are subjected to the domestic realm ignored by men. The caged bird becomes a visible symbol for imprisoned, oppressed women. Its death signals the way patriarchy exercises power over nature and women. Hence, Mrs. Wright's revenge indicates a change in the dynamics of power relations between men and women.

In Glaspell's play, Hale, a farmer and neighbor, famously utters anti-feminist sentiments and claims that "women are used to worrying about trifles" (p. 873). His wife, however, reveals that Mrs. Right suffered in her marriage which turned out to be a form of imprisonment like the cage in which the poor bird lived. Mrs. Hale says that Mrs. Right was lonely, childless, and depressed:

She didn't even belong to the Ladies' Aid. I suppose she felt she couldn't do her part, and then you do not enjoy things when you feel shabby. She used to wear pretty clothes and be lively, when she was Minnie Foster, one of the town girls singing in the choir. But that-oh, that was thirty years ago. (p. 874)

The dead bird was kept in a pretty box and wrapped in a piece of silk because it was dear to her. Since John Wright did not like a singing bird, he killed that desire for life and singing in his wife. The Sheriff and the County Attorney mock women's presumed interest in "trifles." As it turns out, it is men who fail to find the crucial evidence and keep looking outside the real frame of the picture. Their abstract rationalism is countered by the empathy and intuitive insight of women. Carter's story The Bloody Chamber published in the same collection with The Erl-King has the Marquis attempt to decapitate his latest wife, a piano player, who dared to enter his secret torture chamber. The young bride discovers that her rich yet perverse husband has strangled an ex-wife, among many others he killed, who was an opera singer. The wife/narrator observes: "On her throat I could 
see the blue imprint of his stranglers' fingers" (para. 128). The act of strangling and the traces it left on the victim's neck can be viewed as a variation on the theme of decapitation. In Glaspell's play and Carter's stories, beheading and strangling are interrelated. They signify the silencing of birds/women and stripping their voices.

Glaspell's subsequent story A Jury of Her Peers (1917) reworks the main plot and themes of her play Trifles. The Wrights' place where Mrs. Wright lived for about twenty years is described from a distance when viewed by the men and women going there to investigate and assess the crime scene: "It looked very lonesome this cold March morning. It had always been a lonesomelooking place. It was down in a hollow, and the poplar trees around it were lonesome-looking trees" (p. 333). Such a description suggests a rift in the relation between a husband and his wife, and nature here mirrors the cold relation of the Wrights. The women sit in the kitchen, where they find the dead canary, and the bird-cage with a broken door hinge signals the violent suppression of female identity. Mrs. Hale asserts that Mrs. Wright "used to sing real pretty herself" (p. 343) like the canary. On the other hand, the women prove to be smart observers of details and making connections. Mr. Hale's supremacist assumption that "women are used to worrying over trifles" (p. 337) becomes ironic. To figure the strained relationship between the couple, Glaspell has used a canary bird and made Mrs. Wright emotionally attached to it against an austere husband. The death of the bird not only indicates the spiritual or emotional death of the wife Mrs. Wright, but it also hints at the alliance between women and exploited nature. Carter's story The Erl-King builds on similar notions utilized by Glaspell and offers an interesting variation on similar ecofeminist themes. Moreover, both stories thematize caged birds to comment on the privations imposed on women under patriarchy like silencing and marginalization; and both stories end with murdering the aggressor. However, Carter's case is complicated because she represents the preoccupations of another feminist phase and a different historical period. ${ }^{2}$ Since this article is not an analogical study, it does not intend to examine possible influence relations as this would be beyond our scope. Instead, the subordination of nature and the alliance between women and nature in Carter's story The Erl-King are explored in light of ecofeminist implications discussed in this introductory section.

Western feminist literary traditions abound with metaphors of the confinement of woman by a patriarchal culture relegating women to attics, asylums, or the domestic household. In Tremain's Sacred Country (1992), Estelle is a woman driven to madness by the abuse of her domineering husband. As a result, she spends time in an asylum trying to recover from seeing shadows of herself being trapped inside an onion. There, she feels more confined because her worries were quite incomprehensible to those around her. Similarly, in Kingsolver's postcolonial feminist novel The Poisonwood Bible (1998), Orleana Price is another confined woman with no will or life of her own. Her domination by her husband is parallel to the colonization of the Congo to which he takes her and her four daughters, against their will, to fulfill his missionary passion of baptizing Congolese children. Kingsolver draws links between the colonization of the Congo and the subjugation of women. In such works, images of female imprisonment and domination are

Arab World English Journal for Translation \& Literary Studies 
intertwined. Within the same context too, the rare association Carter makes between confined women and birds in her ecofeminist fiction is significant. In her novel Nights at the Circus (1984) the main character, Sophie Fevvers, is a bird-woman who hatches from an egg; she does not know who laid the egg or her real parentage. This aerialist is also the narrator who found herself "in that basket of broken shells and straw" (p. 21). She develops wings and is ready to fly, possibly a hint at liberation from patriarchal constricting structures. Carson (1962) laments the failure in modern societies to integrate human and nature and ascribes that to the indifference of man to the green environment with all its forms and the patriarchal practices of man over nature which silence nonhuman forms and destroy human life. Carson realistically describes an appalling silence which "lay over the fields and woods and marsh" and "a strange stillness" (p. 2) pervading in her yard as a result of the disappearance of birds following extensive use of insecticides to protect man-made gardens from insects. Carson uses the silence of birds and spring to warn against a possible fate for human life itself and presages a set of similar metaphors in literary texts on oppressing the environment for the comfort of humans. The analogy Carson creates between birds and the human condition as a result of the wrong practices of man over the environment resembles analogous literary connections between oppressed nature, in particular birds, and the fate of those who are down our social, political, or cultural hierarchies, for example nature, the 'third' world, the subaltern, and the colonized.

Within the same context of the analogy between the caging or silencing of birds and marginalization are a poem entitled Caged Bird published in the poetry collection Shaker, Why Don't You Sing (1983) and also a memoir (1969) entitled I Know Why the Caged Bird Sings by the African American poet Maya Angelou. Angelou employs the metaphor of caged birds to discuss power and racial relations within the American society. Angelou's poem Caged Bird is pictorial, depicting two birds, one free representing white Americans and another caged bird whose wings are clipped and whose feet are bound by racism. In describing the dilemma of the caged bird, Angelou is detailing the struggle of blacks in racist America; she likens the oppressed African Americans during their struggle for civil rights to caged birds trying to endure the pains of captivity by singing about freedom; the bird "opens his throat to sing...a song of freedom" till the bars of captivity crumble. This might be seen as the wish of the poet herself to confront the ugliness of racism with poems about freedom which can overthrow all bars of segregation and break cages of confinement similar to the Biblical appeal to humans to free themselves from sin: "Free yourself, like a gazelle from the hand of the hunter, like a bird from the snare of the fowler" (p. 116). Such contexts (poetic, fictional, non-fictional, and theoretical) should help us better understand themes of nature, patriarchy, troubled gender roles, and confined birds in Carter's story The Erl-King.

\section{Carter's The Erl-King between Complicity and Critique}

In The Erl-King, Carter uses similar metaphors of entrapment and liberation and similar figurative analogies between constrained women and caged birds. She makes caged birds equal to an exploited nature and similar to the female narrator imprisoned in the Erl-King's wood. However, this ecocritical, feminist nexus should not be unproblematically understood because Carter's postmodern criticism of patriarchal norms also suggests the complicity of women and 
nature in this exploitation and the blurred boundaries between the masculine and the feminine principles.

Linda Hutcheon (2002) articulates this inclusive, ambivalent logic of postmodernism (the accommodating both/and rather than the exclusive either/or) as "the mark of its potentially complicitous critique" (pp. 5-6). Hence, Hutcheon acknowledges that feminists might have issues with postmodernism because it lacks "a theory of agency" (p. 7). Carter's brand of postmodern feminism as manifested in her story The Erl-King conflates man and woman with nature. It revises cultural stereotypes on the active/passive in sexual relations as well as the victim/victimizer binary. Moreover, Carter exposes how women and nature may well be complicit in their own oppression and exploitation. She justifies that through acceptance of multiplex female sexual desire. The result is a critique of patriarchy oppressing women and nature and simultaneously an exposition of different forms of complicity with the oppressor. In Carter's world, both male and female characters have a propensity for sexual corruption and even the enjoyment of erotic desire. And sexual aggressors often end up being victims. ${ }^{3}$ Ambivalence forms the essence of her postmodern approach and unorthodox feminism.

In Germanic mythology, the Erl-King appears as a bearded giant or elf haunting the forest and stealing children or luring them to their death. Goethe's ballad poem on this legend, Der Erlkönig (1782), has a supernatural entity (a fairy elf king), who caused the death of a boy who went to the forest with his father. While in Goethe's ballad the elf-king (a mysterious natural force) does the boy cruel harm despite the father's attempts to rescue his son, Carter's revision of the folk tale makes a girl the potential object of this harm yet twists the conclusion so that the girl survives by murdering this evil king. The setting of The Erl-King is the cold sullen weather of late October, an autumn wood, "when the withered blackberries dangled like their own dour spooks on the discoloured brambles" and the whole atmosphere suggests "the haunting sense of the imminent cessation of being" (para. 1). Acting as a big prison, the enclosing woods swallow incomers, and one cannot easily find a way out (para. 2). This natural trap becomes the site of the harm the ErlKing plans to inflict on the female narrator.

The association between women and nature is manifest from the beginning of the story. Moreover, the complicity of nature with patriarchy is suggested as well: "The trees stir with a noise like taffeta skirts of women who have lost themselves in woods and hunt round helplessly for the way out" (para. 2). The fairy tale dimension (that of the young girl versus evil beast) is also apparent to the reader, and the Erl-King becomes similar to the wicked wolf in the well-known fairy tale, but without the unexpected transformations of the fairy tale:

A young girl would go into the wood as trustingly as Red Riding Hood to her granny's house but this light admits no ambiguities and, here, she will be trapped in her own illusion because everything in the wood is exactly as it seems. (para. 3) 
Carter's deconstruction of the fairy tale is evident because there are no deceiving appearances, masks, or disguises, and the girl's curiosity and desire might be to blame for her subjection to the Erl-King. Thus, Carter seems to reject "the false universalizing inherent in many so-called master narratives of the Western literary tradition" (Brooke, 2004, p. 67). When the female protagonist realizes she is being lured into a trap among the caged birds meant to entertain the Erl-King, she vows rebelliously not to sing. The story resists portraying female victims as simply passive and trusting, which moves the story from a direct indictment of patriarchy into an intricate examination of female sexuality, initiation, and complicitous desire.

In exposing the repressive formations of female gender and sexuality, Carter goes against expectations and constructs "a feminist subjectivity defined as active rather than passive" (Brooke, 2004, p. 68).The girl in this story not only survives but also murders the Erl-King, thus reversing gender stereotypes and patriarchal ideologies. When she goes for walks, in the mornings or "more enticingly, in the evening when the cold darkness settles down," she always goes to the Erl-King and he lays her "down on his bed of rustling straw" where she lies "at the mercy of his huge hand" (para. 19). The repetition of the action of going to the Erl-King signals a conscious intention on the girl's part, especially on sensual evenings. The narrator is susceptible to sexual corruption, which contradicts the myth of female innocence and valued virginity in traditional fairy tales. On the other hand, the Erl-King is described as an "excellent housewife" (para. 18), living in a neat house and using the blessings of nature to his very advantage. Thus, Carter questions typical gender notions related to agency, passivity, and domesticity. The green of the Erl-King's eyes is the color of the woods ("His eyes are quite green, as if from too much looking at the wood," para. 11). When he combs his hair which has "the colour of dead leaves," dead leaves fall out of it (para. 20). Such a description makes the Erl-King, rather than the female narrator, closer to nature, which deconstructs the woman/nature parity.

However, the story immediately establishes a level of empathy between the female narrator, a lonely girlish one, and sad birds: "Piercingly, now, there came again the call of the bird, as desolate as if it came from the throat of the last bird left alive. That call, with all the melancholy of the failing year in it, went directly to my heart" (para. 7). The description allows for ecofeminist relevance and suggests the possible harm the Erl-King will do to the girl narrator. The sense of threat is confirmed when she arrives to his house in a clearing in the forest, in which he lives alone, using nature to his advantage:

His house is made of sticks and stones and has grown a pelt of yellow lichen. Grass and weeds grow in the mossy roof. He chops fallen branches for his fire and draws his water from the stream in a tin pail. (para. 13)

He is sustained by the bounty of the woods, collecting fungi, dandelion, wild strawberries, goat milk, rabbits, and wild garlic. Just as he exploits "mother" nature (herbs, nettles, dandelion, mushrooms, animals, and birds), he has evil plans for the heroine. His first move when she arrives is smiling, putting down his pipe, and inevitably laying his "irrevocable" hand on her (para. 10). Noticing his dark green wood-like eyes, the narrator indicates sexual devouring; she observes: 
"There are some eyes can eat you" (para. 12). The Erl-King's association with the male principle also makes him an embodiment of a mysterious, seductive nature. The narrative assigns him sexual agency and assigns the female narrator passive yet complacent sensuality.

Since he utilizes nature, the Erl-King keeps his singing birds in little cages he makes from osier twigs. His kitchen "shakes and shivers with birdsong from cage upon cage of singing birds, larks and linnets, which he piles up one on another against the wall, a wall of trapped birds" (para. 17). When the narrator objects to his cruel treatment of such birds, he laughs at her "and shows his white, pointed teeth with the spittle gleaming on them" (para. 17). His menacing behavior not only mocks her ignorance but also foreshadows his evil intention of putting her in a similar cage. Hence, the caged birds metaphorically represent confined women and unequal power relations. He tries to seduce her with his stories about nature and with the aromatic, musical room with wood fire giving warmth. But the old broken violin on the wall beside bird cages hints at something wrong. In fact, there is something grotesque about the description of the Erl-King's sexuality: "And nowach! I feel your sharp teeth in the subaqueous depths of your kisses...you sink your teeth into my throat and make me scream" (para. 25). He acts as a sexual predator, exploiting the innocent narrator who visits him on cold mornings or evenings when she goes for walks. Her complicity with the Erl-King in her sexual exploitation can only be defended in terms of loneliness, curiosity, and lack of sexual experience. She views him as "the tender butcher" who showed her "how the price of flesh is love," yet she views herself as a sexual victim, "skin the rabbit, he says! Off come all my clothes" (para. 19). She repeatedly goes to him and he repeatedly takes her to his bed. In this regard, Macsiniuc (2015) contends: "Divested of the sartorial cultural shield, the sign of her humanity, the beastified woman is returned to a primal state of sexuality and desire, in which, paradoxically, she feels entrapped in a more insidious way" (p. 88). Surprisingly, the narrator is complicit in her own dehumanization and sexual victimization. Made naked, she is closer to nature (animals and birds) rather than culture. The Erl-King skinning her like a rabbit shows how he thinks of her in terms of the frail, unresisting animals he devours, or alternatively his "poor" caged birds.

Although the narrator might be complicit in giving him the chance to sexually possess her, her "girlish and delicious loneliness" (para. 5) works in her favor against the experienced Erl-King. In fact, both nature (the wood and its inhabitants in this case) and the female narrator seem complicit in their exploitation. Hence, although the end of the story might suggest liberation and freedom from cages as well as other forms of social or sexual oppression, Carter seems critical of the role of women/nature in their own oppression. For instance, the doves that down on the ErlKing's shoulders are described in negative rather than sympathetic terms as "silly, fat, trusting woodies with the pretty wedding rings round their necks" (para. 20), which enhances what we have already said about the association between women (i.e. the symbolic meaning of wedding rings as the marriage institution and commitment to men) and caged birds. He calls them through his whistle, and "the sweetest singers he will keep in cages" (para. 20). Such naïve birds are both gullible and susceptible. They seem to lack experience or judgment. They are natural creatures subjected to the will of the Erl-King.

Arab World English Journal for Translation \& Literary Studies 
The Erl-King, by contrast, lives in harmony with nature, his hair is "the colour of dead leaves" (para. 20), and he stands still like a tree when birds perch on his shoulders. The narrator realizes that his harmony with nature is part of the reason why she falls for him: "The earth with its fragile fleece of last summer's dying leaves and grasses supports me only out of complicity with him, because his flesh is of the same substance as those leaves that are slowly turning into earth" (para. 20). Just like the unwitting birds, she comes to his call for warmth and food. He enchants her with his music, his dark embraces, the green of his eyes, and his succulent fruits. His enticing whistles and corn attract the birds, and his flesh entices her. The narrator realizes that he is weaving a cage for her too and that his embraces are his tool of seduction. Her belated discovery is that: "His embraces were his enticements and yet, oh yet! they were the braches of which the trap itself was woven" (para. 37). Although she loved him, she knew he could harm her. "I have seen the cage you are weaving for me; it is a very pretty one and I shall sit, thereafter, in my cage among the other singing birds but I - I shall be dumb from spite" (para. 36). She wonders if the songs of his birds might only be the cries of imprisoned birds seeking freedom. She develops ambivalent feelings for him, as she loves him yet does not want to be caged among his birds although he takes a good care of them. Thus, she rejects his trap, and equally rejects the "lullabies for foolish virgins" (para. 38) he might entice her with. From an ecofeminist perspective, the fact that the Erl-King schemed a fate of confinement for the narrator just as he does with the birds builds a case for intertwining women with nature and oppressing both. On the other hand, the fact that the Erl-King stands for raw natural forces makes the narrator resort to her own mysterious nature in seeking the Erl-King.

In order to evade the fate of "foolish virgins" lacking experience, the narrator ironically first succumbs to the Erl-King even though his love is a constricting one. Contrary to the malevolent nature of the Erl-King in Germanic mythology, Carter's character, the Erl-King, is shown as soft and sentimental; his room is musical and aromatic. He is looking for compassion and intimacy for sometimes he lays his head on the narrator's lap and lets her comb his hair. By showing qualities or traits unexpected of the Erl-King's strong character or gender, Carter perhaps imagines how it is like if gender roles and gender stereotypes have been reversed. As he lays his head on her knee, she avoids his enticing green eyes while combing the dead leaves out of his profuse hair. The Erl-King is powerfully seductive, but she is cautious and in control. She does not let him captivate her with his eyes which she recognizes as the gateway to imprisonment and captivity. This is reminiscent of the Biblical warning to man: "Do not lust in your heart for her beauty or let her captivate you with her eyes" (p. 144). Carter is very successful in reversing stereotypical gender traits. The female protagonist is in full control of her desire and does not succumb to the temptation in the seductive eyes of the Erl-King. To Carter, she is smarter than Adam in the Biblical story of man's expulsion from the Garden of Eden and the responsibility of Eve in that. Dissimilar to Adam, the woman decides not to eat the forbidden fruit which will condemn her to confinement and captivity and expel her from the garden of liberty as she looks at the caging of birds as her imminent fate. Her hands shake as she ponders her scheme of murdering him, a scheme similar to that performed by Delilah on the legendary Samson to deprive him of his power: "I shall take two huge handfuls of his rustling hair as he lies half dreaming, half waking, and wind them into ropes, very softly, so he will not wake up, and softly, with hands as gentle as 
rain, I will strangle him with them" (para. 40). Targeting his long hair, she aims at an ambivalent symbol of his potency yet "effeminate" nature. Her plan is then to free the birds from their cages only to have them regain their human form:

Then she will open all the cages and let the birds free; they will change back into young girls, every one, each with the crimson imprint of his love-bite on their throats. She will carve off his great mane with the knife he uses to skin the rabbits; she will string the old fiddle with five single strings of ash-brown hair. (para. 41)

This animal/human metamorphosis is suggestive of the fluid woman/bird divide. The narrator could have been transformed into a caged bird if she continued to accept his wooing and love bites. That could have been followed by a ring placed around her neck just like the other birds he kept, which suggests possession and subordination. In her discussion of Carter's story collection The Bloody Chamber, Krifa (2018) contends that Carter generally employs metamorphoses of humans and animals to transcend gender binaries within a postmodern frame of rewriting fairy tales. Krifa states that Carter "believes in the human constant alteration and continuous progress, as prerequisites to attain the human subjectivity" (p. 58). In fact, her cutting of the hair on his mane is analogous to his own act of stripping her naked, which can be read as "an act of retaliation which places him in an equivalent situation of vulnerability and danger" (Macsiniun, 2015, p. 89). Apparently, Carter reverses the passive role of women in traditional fairy tales (weakness and victimization), creating a strong female capable of murder for the sake of liberation after initial subjection.

However, and in a postmodern fashion, the present and future tense narration does not confirm what exactly happens, and we do not know for sure whether the narrator kills/strangles the Erl-King or just has a fantasy about doing so. In addition, the shift in narrative perspective from first-person narration to third-person narration towards the very end is indicative because it might indicate the schism between her thoughts and actions. Arikan (2016) has maintained that the last scene of the story "is again narrated from the third-person point of view, creating an alienation effect" (p. 121). The contrast here might be between what has been happening to the narrator before and what she will carry out now. Regardless of how we read the conclusion, it is apparent that there is a change in the narrator's mind if not her actions, in the direction of selfdetermination.

The fixed fiddle, which the narrator repairs using the Erl-King's mane, will play music without being touched: "Mother, mother, you have murdered me!" (para. 42). This can be interpreted in terms of the Erl-King exploiting and murdering mother nature or the heroine breaking her bond with her submissive nature that made her come under the authority of the ErlKing. On the one hand, this is a condemnation of the widely-held stereotypical thoughts about gender roles which Carter has reversed mainly by ironically assigning the Erl-King the traits and behaviors of a typical housewife. The Erl-King is excellent in managing his household and his kitchen which, though rustic, he keeps ordered. Moreover, Carter is also critical of how the ErlKing is ironically a punctilious housewife who pays attention to details and cares about minute 
things. Moreover, the Erl-King showers the creatures around him with motherly love as he gives them water and feed. But this is the same kind of love and care that caused the woman protagonist in Charlotte Perkins Gilman's feminist story The Yellow Wallpaper of the late Nineteenth Century to descend into madness because she felt confined by her bordered room and was restrained from her passion of writing by her loving husband who cared about her and brought her to a colonial mansion to recover from postpartum depression. She saw the mansion as a haunted place with many confines, hedges, walls and gates. The whole place felt like a prison with all those confinements and lines that she could not cross. Even the open garden was confining, full of boxbordered paths, and lined with long grape-covered arbors. Hence, feminists like Carter and Gilman suggest that (patriarchal) benevolent or indulgent schemes might be actually constraining and oppressing, and that direct hostility might be softer than masked tenderness.

Within the frame of reversal of expectations encountered more at the end of the story, the music played by the fiddle might indicate how the heroine, being now a sexually experienced woman, murdered her own submissive nature as well as the nature the Erl-King embodies or identifies with. Jyothi (2019) criticizes how "linguistically, women are linked to nature, we exploit 'mother earth', we cut down 'virgin' timber, through this we feminize nature with naturalized women and in this process, we are enforcing mutual subordination" (n. pag.). On the other hand, and from a postmodernist perspective, Carter revises the old patriarchal myth that women are simply analogous to a vulnerable nature. The Erl-King does not differentiate between her and his caged birds and all other non-human natural elements which he keeps under full control. To revoke this association of women with nature, once more, the writer resorts to the technique of reversal, for instead of associating the heroine with nature under their mutual subordination by the Erl-King Carter associates nature with the Erl-King and murders both. By ridding the woods and woman of their oppressor and redeeming their liberty, Carter shows utmost ecofeminist concern over both woman and the natural world with all its non-human forms. Mellor (1997) blames "patriarchy" or "'the patriarchal man" rather than "men per se" who exploit nature for the sake of "progress" causing severe "ecological cost(s)" (p. 44). The female protagonist's redemption of the birds is equivalent to Mellor's ecofeminist call that "women are to be the bridge in a reformed and reformulated social order" (p. 44). The text remains complex in this regard, but it may be well assumed that the story problematically aligns women with nature and empowers their coming together against structures of domination. The last exclamatory sentence in the story ("Mother, mother, you have murdered me!), hence, definitely signals a new start and a shift in power relations, a move from complicity to denial and revolt, or rather from complicity to critique.

\section{Conclusion:}

This article has begun by pointing out the significance of nature and non-human forms of life in Carter's fiction and by drawing analogies between feminism and ecocriticism. The ecocritical relevance of Carter's fiction, it was asserted, has not been adequately examined so far. The article then drew parallels between Glaspell's play "Trifles" and Carter's story "The Erl-King" to enhance the theoretical framework overviewed in the introduction by offering it an applied aspect. Glaspell's play was introduced to help us see the relevance between caged birds and oppressed women, on the one hand, and an insensitive patriarchal culture, on the other hand. The 
discussion has mainly focused on Carter's story to illustrate the linkage between caged birds and imprisoned women under patriarchy. Their liberation by the female narrator at the end of the story is not only a sign of feminist resistance but also an indication of the essential harmony and mutual strength of women and nature against the anthropocentric and humancentric assumptions that the natural world with all its resources is to be exploited for the comfort of human beings and at the same time against the assumption that Eve was made for Adam. It is evident that Carter uses nature and marginalized forms of life (i.e. birds in this case) as a metaphor for gender power relations. She condemns passivity and complicity and suggests that women should move beyond their complicity with the oppressor if they are to free themselves from the chains of submission. Simultaneously, Carter offers a subtle vision on women's natural sexual impulses and spontaneous sensuality which make them willing victims or acquiescent partners.

As a postmodernist writer, however, Carter unsettles the myth that women are simply close to nature or passively/sexually violated. Thus, and in the process, she subverts traditional feminist logic with a multiplicity of positions and voices beyond dichotomous or monolithic logic. Carter does not only defend women as would be expected in typical feminist texts. Rather, she justifies female desire and sexuality in the very process of articulating a feminist poetics via her commitment to nature and minor forms of life. Reversing patriarchal expectations, Carter describes the Erl-King in terms of efficient housewifery, passive death, and effeminate looks. Alternatively, the depiction of the female narrator moves from sexual objectification to agency and the ability to murder. Therefore, Carter's story is ambivalent, critical of patriarchy and simultaneously exposing the complicity of women in their own oppression and their willing correspondence to a heterogenous, sensual nature. To illustrate imagery of confinement and the figurative association between birds and women, the article incorporated a few literary and theoretical allusions. It should be concluded that Carter subverts patriarchy from within, questioning the alliance between women and nature on the one hand, through the figure of the Erl-King, exposing brittle gender norms, and pointing out the possible complicity of women in their oppression or the inescapability of sexual liaisons.

\section{Notes}

${ }^{1}$ Associations can be made among feminism, postcolonialism, and ecocriticism. All three literary and cultural approaches share analyses of power, ideology, and inequities. In addition to the linkage we are suggesting between women and nonhuman elements, on the one hand, and nature/environment, on the other hand, we can argue parallels between the subaltern colonized or settlements and an exploited nature. The intersection between postcolonialism and ecocriticism was best captured in Huggan's and Tiffin's book (2010). See References.

${ }^{2}$ Glaspell was an American playwright who died in 1948, when the English writer Carter was only eight years old. Carter died in 1992. While Glaspell's work reflects the claims of conventional feminism, Carter's approach seems more intricate centering on postmodernism, gender politics, and a feminist rewriting of many fairy tales and folk stories.

${ }^{3}$ In Carter's story The Bloody Chamber, the young teenage bride discovers the corruptibility of her nature when she awakens to sexual desire after her husband departs on a business errand and when she begins a curious journey inside his castle in order to understand his mysterious past. 
When the husband, a Marquis, tries to decapitate her in response to her disobeying of his command not to enter his secret torture chamber, he is turned into a victim by the bride's mother who suddenly arrives to the scene and shoots him in the head.

\section{About the Authors:}

Dr. Shadi S. Neimneh is associate professor of literary and cultural studies in the English department at Hashemite University, Jordan. He has published widely on modern literature and cultural studies. https://orcid.org/0000-0003-3041-5306

Dr. Halla A. Shureteh is associate professor of literature and translation studies in the English department at Hashemite University, Jordan. She has taught and published in both areas.

\section{References}

Angelou, M. (1993). I Know Why the Caged Bird Sings: A Black Woman Tells of Her Painful Growth to Maturity. New York: Bantam.

Angelou, M. (1983). Shaker, Why Don't You Sing. New York: Random House.

Arikan, S. (2016). Angela Carter's The Bloody Chamber: A Feminist Stylistic Approach. Firat University Journal of Social Sciences, 26(2), 117-130.

Barry, P. (2009). Beginning Theory: An Introduction to Literary and Cultural Theory ( $3^{\text {rd }}$ ed.). Manchester: Manchester UP.

Bennett, A. \& Royle, N. (2009). An Introduction to Literature, Criticism and Theory (4 ${ }^{\text {th }}$ ed.). Harlow: Longman.

Brooke, P. (2004). Lyons and Tigers and Wolves-Oh My! Revisionary Fairy Tales in the Work of Angela Carter. Critical Survey, 16 (1), 67-88.

Carson, R. (1962). Silent Spring. Boston: Houghton Mifflin.

Carter, A. (1995). The Bloody Chamber. Burning Your Boat: The Collected Short Stories. New York: Penguin. E-Text.

Carter, A. (1995). The Erl-King. Burning Your Boat: The Collected Short Stories. New York: Penguin. E-Text.

Carter, A. (1985). Nights at the Circus. New York: Viking.

De Beauvoir, S. (2001). From The Second Sex. In V. Leitch (ed.), The Norton Anthology of Theory and Criticism (1406-1414). New York: Norton.

Derrida, J. (2008). The Animal That Therefore I Am. (D. Wills, trans.). In M. Marie-Louise (ed.). New York: Fordham UP.

Dobie, A. B. (2012). Theory into Practice: An Introduction to Literary Criticism ( ${ }^{\text {rd }}$ International ed.). Wadsworth, Cengage.

Gilman, C. P. (2003). The Yellow Wallpaper. In N. Baym (ed.), Norton Anthology of American Literature 1865-1914 (6 $6^{\text {th }}$ ed., 832-844). New York: Norton Company.

Glaspell, S. (1993). A Jury of Her Peers. In L. Perrine \& T. R. Arp (eds.), Literature:Structure, Sound, and Sense (6 ${ }^{\text {th }}$ ed., 332-348). Fort Worth: Harcourt.

Glaspell, S. (1993). Trifles. In L. Perrine \& T. R. Arp, (eds.), Literature: Structure, Sound, and Sense. (6 $6^{\text {th }}$ ed., 870-880). Fort Worth: Harcourt. 
Goethe, J. W. (1782). The Erl-King. (E Zeydel, 1955, trans.). Germanstories.vcu.edu Huggan, G. \& Tiffin, H. (2010). Postcolonial Ecocriticism: Literature, Animals, Environment. London: Routledge.

Hutcheon, L. (2002). Postmodern Afterthoughts. Wascana Review, 37 (1), 5-12.

Jyothi, A. (2019). An Ecofeminist Reading of Select Poems of Dattatreya Ramachandra Bendre/Da. Ra. Bendre/Bendre. Language in India. 19 (5). Available from: http://0g100ohn8.y.http.web.b.ebscohost.com.hu.proxy.coeelibrary.com/ehost/pdfviewer/pdfviewer?vid=5\&sid=77bccd69-dd3a-4b90-874274f44461fcfd\%40sessionmgr101

Kingsolver, B. (1999). The Poisonwood Bible. New York: Harper Perennial.

Krifa, W. (2018). Angela Carter's The Bloody Chamber: A Hermeneutic Perspective. International Journal of Arts and Social Science, 1(4), 57-61. Available from: www.ijassjournal.com

Macsiniuc, C. (2015). Sartorial Rhetoric and Gender Roles in Angela Carter's The Bloody Chamber. Meridian Critic, 24(1), 79-91.

Mellor, M. (1997). Feminism \& Ecology. New York: New York University Press.

The One Year Bible: The Entire New International Version Arranged in 365 Daily Readings. (2015). Illinois: Tyndale House Publishers.

Selden, R., et al. (2005). A Reader's Guide to Contemporary Literary Theory. (5 ${ }^{\text {th }}$ ed.). Harlow: Pearson.

Tremain, R. (2011). Sacred Country. London: Vintage Books.

Tyson, L. (2006). Critical Theory Today: A User-Friendly Guide. (2 $2^{\text {nd }}$ ed.). New York: Routledge, Vakoch, D., ed. (2012). Feminist Ecocriticism: Environment, Women, and Literature. Lanham, MD: Lexington Books. 